Article

\title{
Linking ABCC6 Deficiency in Primary Human Dermal Fibroblasts of PXE Patients to p21-Mediated Premature Cellular Senescence and the Development of a Proinflammatory Secretory Phenotype
}

\author{
Janina Tiemann, Thomas Wagner, Christopher Lindenkamp, Ricarda Plümers $\mathbb{B}^{0}$, Isabel Faust (D), \\ Cornelius Knabbe and Doris Hendig *(1) \\ Institut für Laboratoriums-und Transfusionsmedizin, Herz-und Diabeteszentrum Nordrhein-Westfalen, \\ Universitätsklinik der Ruhr-Universität Bochum, 32545 Bad Oeynhausen, Germany; jtiemann@hdz-nrw.de (J.T.); \\ thomas.wagner01@gmx.de (T.W.); clindenkamp@hdz-nrw.de (C.L.); rpluemers@hdz-nrw.de (R.P.); \\ ifaust@hdz-nrw.de (I.F.); cknabbe@hdz-nrw.de (C.K.) \\ * Correspondence: dhendig@hdz-nrw.de; Tel.: +49-5731-97-3816
}

Received: 18 November 2020; Accepted: 17 December 2020; Published: 18 December 2020

\begin{abstract}
Pseudoxanthoma elasticum (PXE) is a rare autosomal-recessive disorder that is mainly caused by mutations in the ATP-binding cassette sub-family $C$ member 6 (ABCC6) gene. Clinically PXE is characterized by a loss of skin elasticity, arteriosclerosis or visual impairments. It also shares some molecular characteristics with known premature aging syndromes like the Hutchinson-Gilford progeria syndrome (HGPS). However, little is known about accelerated aging processes, especially on a cellular level for PXE now. Therefore, this study was performed to reveal a potential connection between premature cellular aging and PXE pathogenesis by analyzing cellular senescence, a corresponding secretory phenotype and relevant factors of the cell cycle control in primary human dermal fibroblasts of PXE patients. Here, we could show an increased senescence-associated $\beta$-galactosidase (SA- $\beta$-Gal) activity as well as an increased expression of proinflammatory factors of a senescence-associated secretory phenotype (SASP) like interleukin 6 (IL6) and monocyte chemoattractant protein-1 (MCP1). We further observed an increased gene expression of the cyclin-dependent kinase inhibitor (CDKI) $p 21$, but no simultaneous induction of $p 53$ gene expression. These data indicate that PXE is associated with premature cellular senescence, which is possibly triggered by a p53-independent $\mathrm{p} 21$-mediated mechanism leading to a proinflammatory secretory phenotype.
\end{abstract}

Keywords: pseudoxanthoma elasticum; cellular senescence; senescence-associated secretory phenotype

\section{Introduction}

Pseudoxanthoma elasticum (PXE) is a rare autosomal-recessive disorder that is characterized by calcification and fragmentation of elastic fibers. This leads to ectopic mineralization of connective tissue, causing a loss of skin elasticity with strong wrinkle formation, arteriosclerosis and the development of angioid streaks, which can trigger choroidal neovascularization, possibly ending up in blindness [1]. The underlying genetic defects are mutations in the ATP-binding cassette sub-family C member 6 (ABCC6) gene resulting in a deficiency of the encoded ABC-transporter protein. ABCC6 is mainly expressed in the liver and just to a lesser extent in peripheral, but primarily affected tissues. Although over 300 possible PXE-causing ABCC6 mutations are revealed by now, the physiological substrate of the $A B C C 6$ transporter is still unknown [1-4]. 
However, studies revealed that PXE shares some molecular characteristics with other heritable diseases like the Hutchinson-Gilford progeria syndrome (HGPS). Thus, HGPS and PXE are characterized by a disturbed pyrophosphate (PPi) homeostasis with an increase in alkaline phosphatase activity and decreased ATP and PPi plasma levels leading to calcification processes in both cases [5-7]. Furthermore, it was shown that therapy with statins and bisphosphonates could be advantageous for PXE as well as HGPS patients. As the pathogenesis of HGPS is comparatively well-known, and patients clearly show accelerated aging symptoms, HGPS is classified as a premature aging syndrome [7-10]. Those accelerated aging processes in HGPS patients are promoted to a considerable extent by an increase in cellular senescence due to the inherited genetic defect [11]. Cellular senescence itself is categorized as a hallmark of aging and is, thus, further defined as a permanent growth arrest of aged and/or damaged cells to avoid further spreading of the cellular damage or malignant degeneration. As a logical consequence, the amount of senescent cells increases during the course of aging as cellular damages accumulate stronger and/or the clearance of senescent cells due to an attenuated immune response is decreased. Besides the positive effect of tumor suppression, senescent cells also provoke destructive effects as an accumulation of senescent cells can induce new or further promote existing pathologies because those cells differ in expression and secretion profiles from proliferating cells. These differences include, e.g., insoluble factors and proteins as chemokines, growth factors and proteases, which modulate the tissue microenvironment and affect cellular communication in an autocrine or paracrine manner [12].

With respect to the similarities between HGPS and PXE, several known molecular characteristics of PXE could possibly be connected to aging and cellular senescence but are barely discussed or intensively evaluated against this background. Thus, senescent cells can, e.g., accelerate wound healing by inducing myofibroblast differentiation [13]. Faust et al. demonstrated a faster wound healing of PXE fibroblasts compared to normal human dermal fibroblasts (NHDF) in vitro [14]. Studies of Diekmann et al. showed increased levels of the matrix metalloproteinases (MMP) -2 and MMP-9 in PXE patients [15]. MMPs often contribute to the secretory phenotype of senescent cells and are also associated with choroidal neovascularization, a characteristic of age-related macular degeneration. Choroidal neovascularization is also a clinical manifestation seen for PXE patients $[12,16,17]$. Additionally, a study of Miglionico et al. showed an increase in cellular senescence in stable $A B C C 6$ knockdown HepG2 clones, probably by induction of reductive stress and p21 expression [18]. However, hepatocytes indeed express high levels of $A B C C 6$ under healthy conditions but are not primarily affected by PXE [19]. Thus, it raises the question of whether a potential increase in the number of senescent cells and, therefore, possible accelerated aging processes in peripheral tissues of PXE patients play a role in PXE pathogenesis, although ABCC6 is just barely expressed in these tissues anyway. Unfortunately, little is known about the proliferative status and a corresponding secretory phenotype of cells in peripheral tissues of PXE patients. Thus, the evaluation of a potential senescent phenotype of primary human dermal fibroblasts of PXE patients could contribute to the understanding of the molecular PXE pathogenesis within affected peripheral tissues. As it is already known that lipid metabolism plays an important role in PXE pathogenesis [20], the cultivation of the primary human dermal fibroblasts of PXE patients in a medium with lipoprotein depleted fetal calf serum (LPDS) probably further reveals effects that would be otherwise potentially covert by an excess of exogenous lipoproteins when conventional fetal calf serum (FCS) is used. By analyzing key factors of a senescence phenotype, we uncovered a probably direct effect of an $A B C C 6$ deficiency on the proliferative status and a corresponding secretory phenotype of affected cells in peripheral tissues.

\section{Results}

\subsection{Altered Cell Morphology and Increased Senescence-Associated- $\beta$-Gal (SA- $\beta$-Gal) Activity}

Prominent factors of cellular senescence are an altered cell morphology and an increased SA- $\beta$-Gal activity. As seen in Figure 1A, PXE fibroblasts showed an aberrant cell morphology compared to NHDF 
when cultivated in medium with 10\% FCS as well as in medium with 10\% LPDS. Cell morphology of PXE fibroblasts changed from elongated shape to flattened morphology. In addition to this, PXE fibroblasts showed increased staining for SA- $\beta$-Gal activity compared to NHDF in both media. As shown in Figure 1B fluorescence signal of SA- $\beta$-Gal activity increased significantly in PXE fibroblasts in medium supplemented with 10\% FCS (control: $6.52 \pm 0.20$, PXE: $10.05 \pm 0.45 ; p \leq 0.001$ ) as well as in medium supplemented with 10\% LPDS (control: $6.21 \pm 0.34$, PXE: $8.75 \pm 0.28 ; p \leq 0.001$ ). Furthermore, fluorescence signal for SA- $\beta$-Gal activity was significantly decreased in PXE fibroblasts cultivated in $10 \%$ LPDS compared to PXE fibroblasts cultivated in 10\% FCS (PXE in 10\% FCS: $10.06 \pm 0.45$, PXE in 10\% LPDS: $8.75 \pm 0.28 ; p \leq 0.05)$. No changes were observed between NHDF in both media.

A

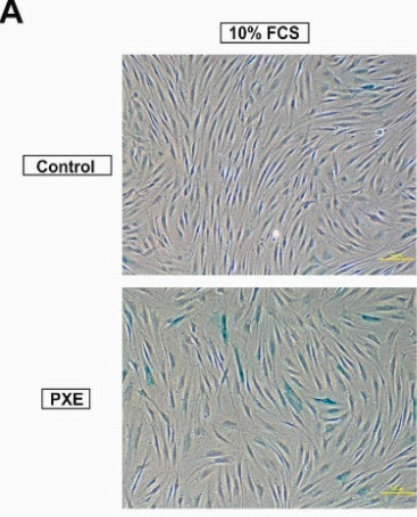

C
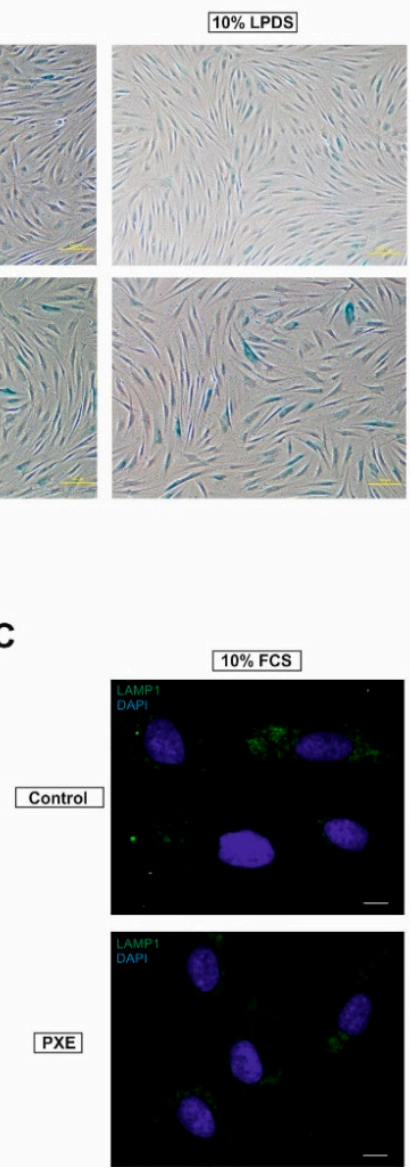

B

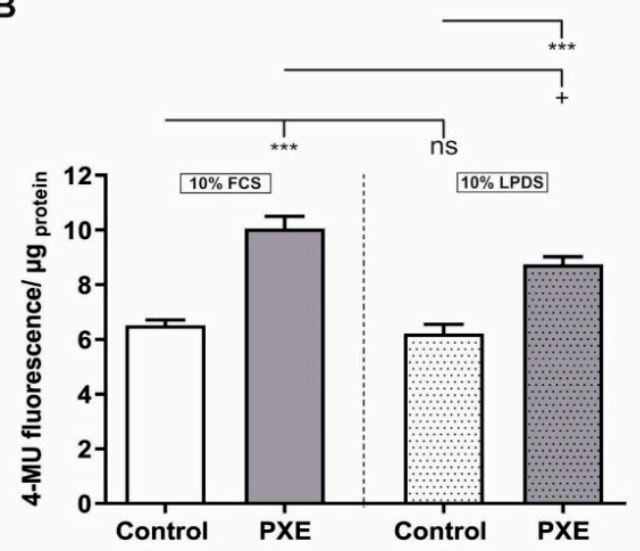

$10 \%$ LPDS

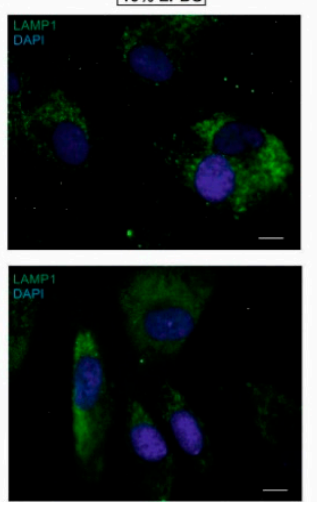

Figure 1. SA- $\beta$-Gal activity and immunofluorescence microscopy of LAMP1 for pseudoxanthoma elasticum (PXE) fibroblasts and normal human dermal fibroblasts (NHDF). Fibroblasts were cultivated for $72 \mathrm{~h}$ in medium with $10 \%$ fetal calf serum (FCS) or 10\% lipoprotein-deficient fetal calf serum (LPDS). (A) Qualitative senescence assay for PXE fibroblasts $(n=3)$ and NHDF $(n=3)$. Representative images are shown. Scale bar: $100 \mu \mathrm{m}$. (B) Quantitative senescence assay for PXE fibroblasts (gray, $n=3$ ) and NHDF (white, $n=3$ ). Data are shown as mean \pm SEM. Control/ PXE: ${ }^{* * *} p \leq 0.001 .10 \%$ FCS $/ 10 \%$ LPDS: $+p \leq 0.05$; ns $p>0.05$. (C) Immunofluorescence microscopy of LAMP1 (green) for PXE fibroblasts $(n=3)$ and NHDF $(n=3)$. Cell nuclei were counterstained with DAPI (blue). Representative images are shown. Scale bar: $10 \mu \mathrm{m}$.

An increase in SA- $\beta$-Gal activity is often associated with a change in lysosomal mass or an increase in $\beta$-galactosidase activity or lysosomal protein concentration. Thus, we analyzed lysosomal-associated membrane protein (LAMP) 1, a lysosomal protein, to evaluate a potential accumulation of lysosomes. An increase in LAMP1 was detected for PXE fibroblasts as well as for NHDF when cultivated in 
medium with 10\% LPDS compared to cultivation in medium with 10\% FCS (Figure 1C). No significant changes for LAMP1 were seen between PXE fibroblasts and NHDF.

\subsection{Aberrant Lamin B1 (LMNB1) Gene, but No Changes in Protein Expression}

Besides the increase in SA- $\beta$-Gal activity, further studies showed that a loss of the LMNB1 gene and lamin B1 protein expression is associated with cellular senescence [21-23]. No changes in the LMNB1 gene as well as in lamin B1 protein expression were observed for PXE fibroblasts compared to NHDF when cultivated in a medium with $10 \%$ FCS (Figure 2A,B). On the application of $10 \%$ LPDS, a significant decrease of $L M N B 1$ gene expression was detected for PXE fibroblasts compared to NHDF (control: $0.66 \pm 0.04$, PXE: $0.27 \pm 0.03 ; p \leq 0.001$ ). Accordingly, a significant decrease for $L M N B 1$ gene expression could be seen for PXE fibroblasts cultivated in 10\% LPDS compared to PXE fibroblasts cultivated in 10\% FCS (PXE in 10\% FCS: $0.70 \pm 0.12$, PXE in 10\% LPDS: $0.27 \pm 0.03 ; p \leq 0.01$ ). However, no significant changes were observed for lamin B1 protein level for PXE fibroblasts compared to NHDF under these conditions.

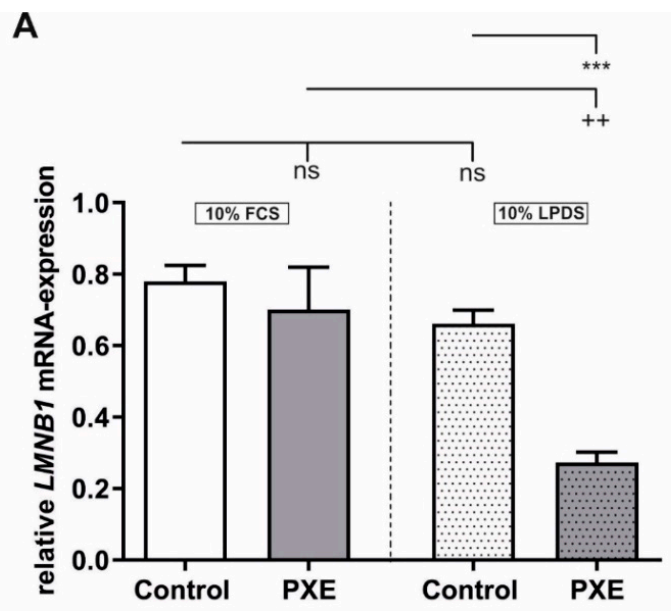

B
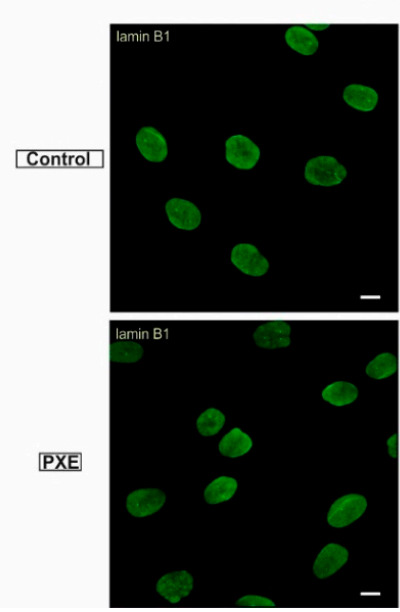

$10 \%$ FCS
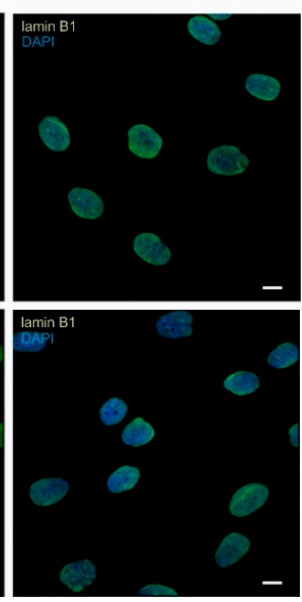

$10 \%$ LPDS
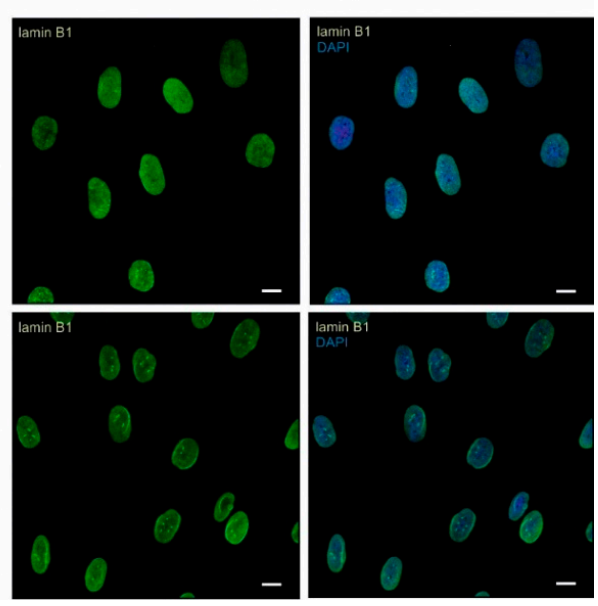

Figure 2. Relative $L M N B 1 \mathrm{mRNA}$-expression and immunofluorescence microscopy of lamin B1 for PXE fibroblasts and NHDF (A) Relative LMNB1 mRNA-expression of PXE fibroblasts (gray, $n=3$ ) and NHDF (white, $n=3$ ) after 24 h cultivation in $10 \%$ FCS or $10 \%$ LPDS. Data are shown as mean \pm SEM. Control/PXE: ${ }^{* * *} p \leq 0.001$; ns $p>0.05$. 10\% FCS/ 10\% LPDS: $++p \leq 0.01$; ns $p>0.05$. (B) Immunofluorescence microscopy of lamin B1 (green) for PXE fibroblasts $(n=3)$ and NHDF $(n=3)$ after $72 \mathrm{~h}$ cultivation in 10\% FCS or 10\% LPDS. Cell nuclei were counterstained with DAPI (blue). Representative images are shown. Scale bar: $10 \mu \mathrm{m}$. 


\subsection{Alteration in Gene Expression of the Cyclin-Dependent Kinase Inhibitors (CDKI) $p 21$ and $p 27$}

The initiation of cellular senescence is dependent on different CDKIs, which suppress the phosphorylation of the retinoblastoma protein (pRB) [24,25]. Thus, we analyzed the CDKIs $p 27$, $p 21$ and $p 53$. As seen in Figure 3A a significant decrease in $p 27$ gene expression was detected for PXE fibroblasts compared to NHDF when cultivated in 10\% FCS (control: $1.81 \pm 0.27$, PXE: $0.95 \pm 0.12$; $p \leq 0.05$ ) as well as in 10\% LPDS (control: $1.39 \pm 0.22$, PXE: $0.55 \pm 0.06 ; p \leq 0.01$ ). Additionally, a significant downregulation of $p 27$ gene expression was observed for PXE fibroblasts cultivated in $10 \%$ LPDS when compared to PXE fibroblasts cultivated in 10\% FCS (PXE in 10\% FCS: $0.95 \pm 0.12$, PXE in $10 \%$ LPDS: $0.55 \pm 0.06 ; p \leq 0.05$ ). For $p 21$ mRNA expression, a significant increase was detected in PXE fibroblasts compared to NHDF when cultivated in medium with $10 \%$ FCS (control: $0.84 \pm 0.10$, PXE: $3.20 \pm 0.40 ; p \leq 0.001$ ) as well as in medium with 10\% LPDS (control: $1.20 \pm 0.16$; PXE: $2.63 \pm 0.42$; $p \leq 0.05)$. No significant changes were observed between the different media. As seen in Figure 3C, no significant changes in $p 53$ gene expression were seen for PXE fibroblasts compared to NHDF when cultivated in a medium with 10\% FCS. A significant increase in $p 53$ gene expression was observed for control fibroblasts cultivated in 10\% LPDS compared to control fibroblasts when cultivated in $10 \%$ FCS (control in 10\% FCS: $0.75 \pm 0.09$, control in 10\% LPDS: $1.38 \pm 0.16 ; p \leq 0.01$ ). In accordance with this, a significant decrease was detected for PXE fibroblasts cultivated in 10\% LPDS when compared to NHDF also cultivated in 10\% LPDS (control: $1.38 \pm 0.16$, PXE: $0.82 \pm 0.11 ; p \leq 0.01$ ). No differences in $p 53$ gene expression were detected for PXE fibroblasts between the different media. We further analyzed different factors of cell cycle control. As seen in Table 1, no significant changes in protein concentration for the listed proteins of cell cycle control, which are measured by cell cycle antibody array, were detected for PXE fibroblasts compared to controls when cultivated in 10\% LPDS.

Table 1. Cell cycle antibody array data. Shown are the mean signal intensities of spots and the ratio of PXE and control. PXE/control ratios of 2 or 0.5 are considered statistically significant.

\begin{tabular}{|c|c|c|c|c|}
\hline \multirow{2}{*}{ Array Position } & \multirow{2}{*}{ Protein } & \multicolumn{2}{|c|}{ Mean Signal Intensity of Spots } & \multirow{2}{*}{ Ratio PXE/Control } \\
\hline & & Control & PXE & \\
\hline Block 1, No. 5 & Cyclin B1 & 585 & 492 & 0.84 \\
\hline Block 1, No. 6 & Cyclin C & 284 & 260 & 0.92 \\
\hline Block 1, No. 7 & Cyclin E & 2237 & 1715 & 0.77 \\
\hline Block 1, No. 8 & Cdk3 & 964 & 887 & 0.92 \\
\hline Block 1, No. 9 & Cdk8 & 560 & 514 & 0.92 \\
\hline Block 1, No. 10 & CDC37 & 284 & 262 & 0.92 \\
\hline Block 1, No. 18 & APC11 & 401 & 380 & 0.95 \\
\hline Block 2 No. 8 & $\mathrm{Cdk} 1 / \mathrm{p} 34^{\mathrm{cdc} 2}$ & 901 & 772 & 0.86 \\
\hline Block 2, No. 9 & Cyclin D1 & 259 & 228 & 0.88 \\
\hline Block 2, No. 14 & $\mathrm{p} 21^{\text {WAF1 }}$ & 240 & 262 & 1.09 \\
\hline Block 2, No. 17 & $\mathrm{E} 2 \mathrm{~F}-2$ & 302 & 335 & 1.11 \\
\hline Block 3, No. 10 & p130 cas & 284 & 332 & 1.17 \\
\hline Block 4, No. 5 & Ki67 & 304 & 257 & 0.85 \\
\hline Block 4, No. 6 & Chk1 & 518 & 424 & 0.82 \\
\hline Block 4, No. 7 & 14.3.3, Pan & 682 & 866 & 1.27 \\
\hline Block 4, No. 8 & Cullin-3 (CUL-3) & 4227 & 3821 & 0.90 \\
\hline Block 4, No. 12 & GSK3b & 1733 & 1153 & 0.67 \\
\hline Block 4, No. 13 & $\mathrm{p} 19^{\mathrm{ARF}}$ & 2247 & 1994 & 0.89 \\
\hline Block 4, No. 14 & p57 Kip2 & 310 & 258 & 0.83 \\
\hline
\end{tabular}


A

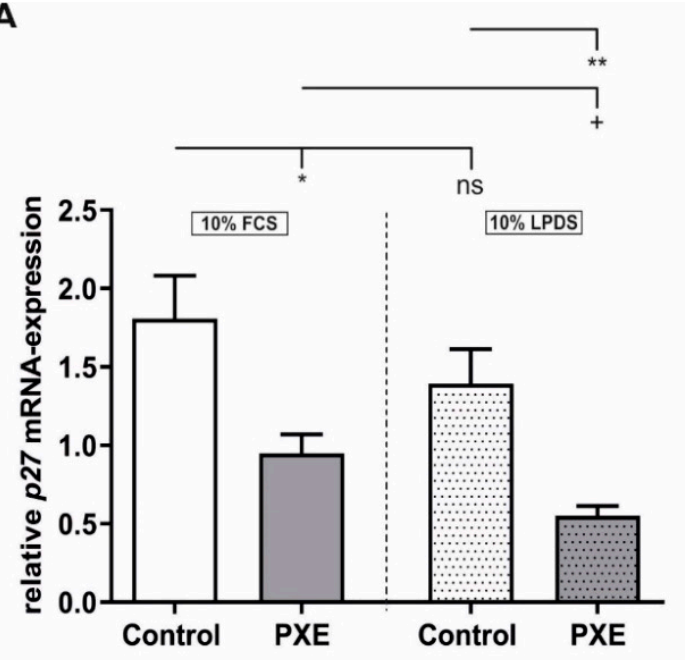

B

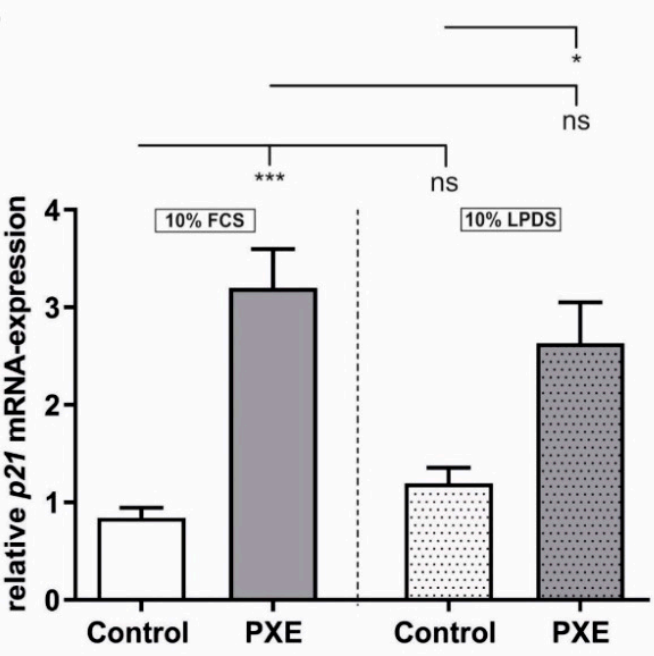

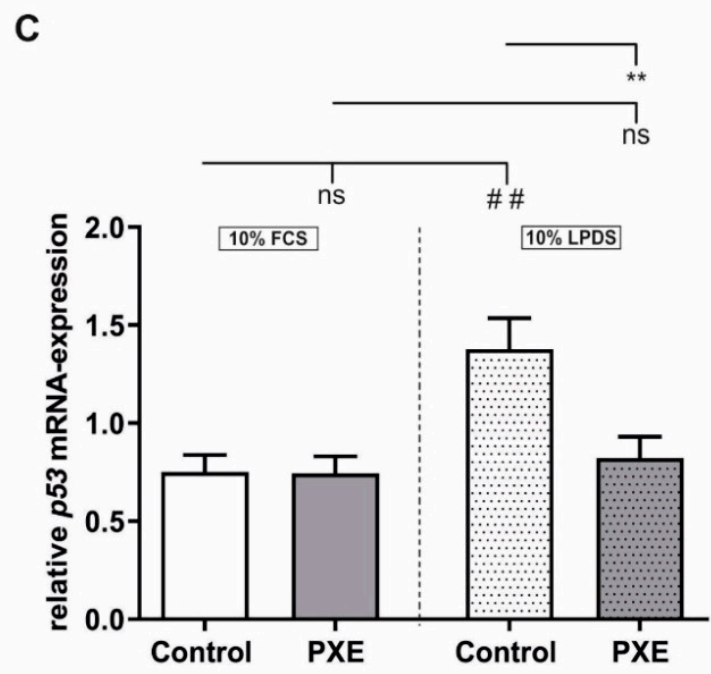

Figure 3. Relative $p 27, p 21$ und $p 53$ mRNA-expression of PXE fibroblasts and NHDF. Fibroblasts were cultivated for $24 \mathrm{~h}$ in medium with $10 \%$ FCS or $10 \%$ LPDS. (A) Relative $p 27$ mRNA-expression of PXE fibroblasts (gray, $n=3$ ) and NHDF (white, $n=3$ ). (B) Relative $p 21$ mRNA-expression of PXE fibroblasts (gray, $n=3$ ) and NHDF (white, $n=3$ ). (C) Relative $p 53$ mRNA-expression of PXE fibroblasts (gray, $n=3$ ) and NHDF (white, $n=3$ ). Data are shown as mean \pm SEM. Control/ PXE: ${ }^{*} p \leq 0.05 ;{ }^{* *} p \leq 0.01$; $* * * \quad p \leq 0.001$; ns $p>0.05$. 10\% FCS/ 10\% LPDS: $+p \leq 0.05$; \#\# $p \leq 0.01$; ns $p>0.05$.

\subsection{Strong Increase in Interleukin 6 (IL6) Gene and Protein Expression}

A well-known characteristic of senescent cells is the development of a senescence associated secretory phenotype (SASP) consisting of different proinflammatory factors like IL6 or monocyte chemoattractant protein 1 (MCP1). For the IL6 gene expression (Figure 4A) and for protein concentration in supernatants (Figure 4B), a strong induction was observed for PXE fibroblasts compared to NHDF when cultivated in medium with 10\% FCS (mRNA; control: $2.03 \pm 0.34$; PXE: $48.68 \pm 8.46 ; p \leq 0.001$; Protein; control: $3.17 \pm 0.65$; PXE: $137.10 \pm 35.28 ; p \geq 0.001$ ) as wells as when cultivated in medium with 10\% LPDS (mRNA; control: $1.66 \pm 0.29$, PXE: $50.13 \pm 10.56 ; p \leq 0.001$; Protein; control: $2.53 \pm 0.43$; PXE: $149.8 \pm 33.47 ; p \leq 0.001)$. As seen in Figure 4C,D MCP1 gene expression and protein concentration in supernatants were increased in PXE fibroblasts compared to NHDF in both media, but only the upregulation of MCP1 gene expression in PXE fibroblasts compared to NHDF when cultivated in medium with 10\% LPDS reached statistical significance (control: $0.58 \pm 0.06$, PXE: $2.43 \pm 0.41 ; p \leq 0.001$ ). Furthermore, $M C P 1$ gene expression showed a significant decrease for control fibroblasts cultivated 
in 10\% LPDS compared to control fibroblast cultivated in 10\% FCS (control in 10\% FCS: $0.72 \pm 0.06$; control in 10\% LPDS: $0.58 \pm 0.06 ; p \leq 0.05$ ). No significant differences were observed for Intercellular adhesion molecule 1 (ICAM1) gene expression.

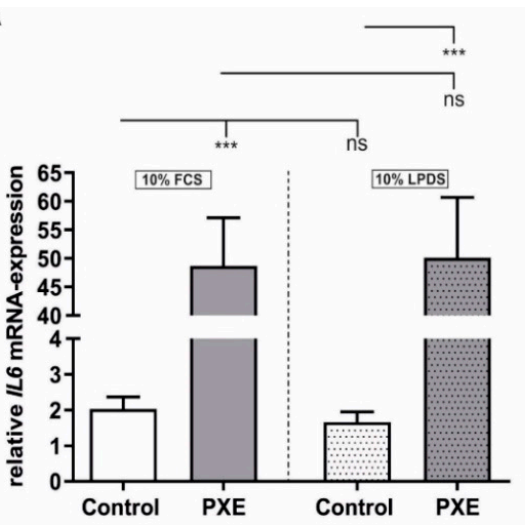

C

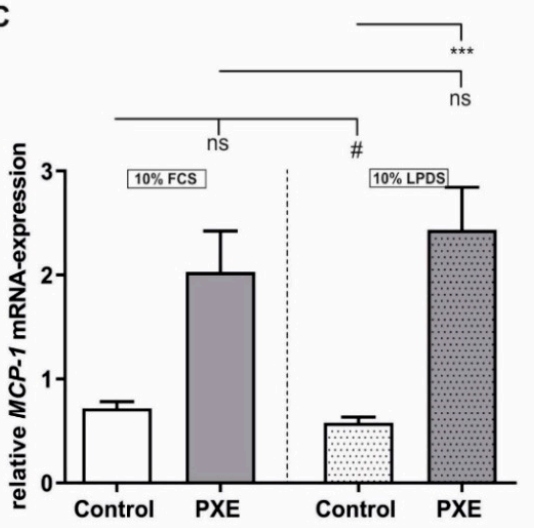

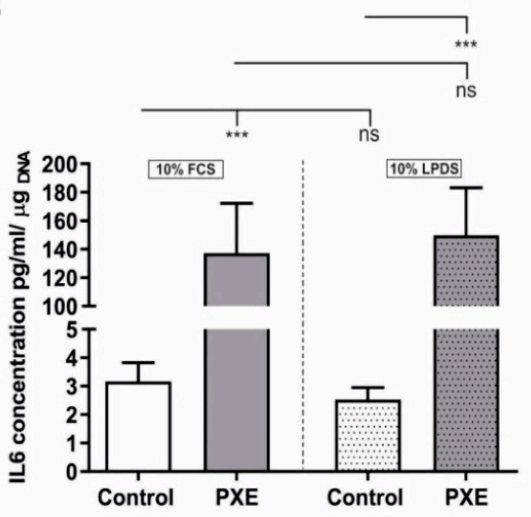

D

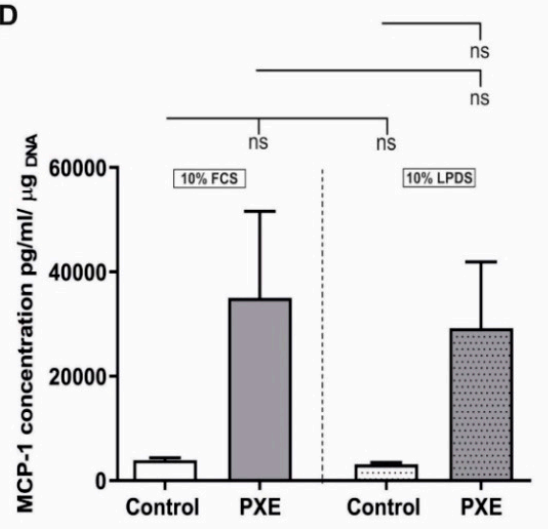

$\mathbf{E}$

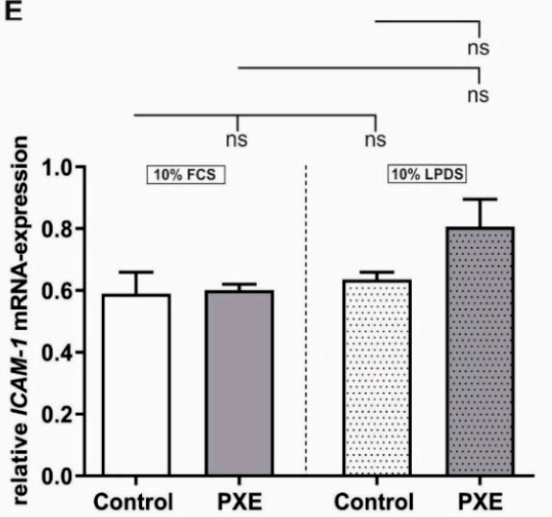

Figure 4. Relative mRNA-expression und protein expression of proinflammatory factors in PXE fibroblasts and NHDF. Fibroblasts were cultivated for $21 \mathrm{~d}$ in medium with $10 \%$ FCS or 10\% LPDS. (A) Relative IL6 mRNA-expression of PXE fibroblasts (gray, $n=3$ ) and NHDF (white, $n=3$ ). (B) IL6 protein concentration in supernatants of PXE fibroblasts (gray, $n=3$ ) and NHDF (white, $n=3$ ). (C) Relative MCP1 mRNA-expression of PXE fibroblasts (gray, $n=3$ ) and NHDF (white, $n=3$ ). (D) MCP1 protein concentration in supernatants of PXE fibroblasts (gray, $n=3$ ) and NHDF (white, $n=3$ ). (E) Relative ICAM1 mRNA-expression of PXE fibroblasts (gray, $n=3$ ) and NHDF (white, $n=3$ ). Data are shown as mean \pm SEM. Control/PXE: ${ }^{* * *} p \leq 0.001$; ns $p>0.05$. 10\% FCS/10\% LPDS: \# $p \leq 0.05$; ns $p>0.05$. 


\section{Discussion}

PXE is a rare autosomal-recessive disorder caused by mutations in the $A B C C 6$ gene, which lead to a deficiency in the corresponding ABC-transporter protein [1]. Although several molecular characteristics of PXE direct towards a potential association with premature cellular senescence and accelerated aging processes [5-7], little is known, especially about the potential involvement of cells of peripheral tissues. Because of this, we analyzed different senescence-associated factors in primary human dermal fibroblasts of PXE patients to further evaluate premature aging processes in peripheral tissues. As previous studies showed that lipid metabolism might play an important role in PXE pathogenesis [20], fibroblasts were cultured in a medium supplemented with $10 \%$ FCS or $10 \%$ LPDS. LPDS was especially applied to reveal effects that would be otherwise potentially covert by an excess of exogenous lipoproteins when conventional FCS is used.

The first indications pointing towards cellular senescence are morphological changes. Fibroblasts undergo cellular senescence change from an elongated shape to an enlarged and flattened irregular cell morphology [26,27]. These morphological changes were also seen here for PXE fibroblasts compared to NHDF. Another senescence-associated biomarker is the SA- $\beta$-Gal activity, which is increased in senescent cells. $\beta$-galactosidase is a lysosomal protein with a $\mathrm{pH}$ optimum between 4.0 and 4.5. In the case of cellular senescence, the SA- $\beta$-Gal activity raises to a degree where it can even be detected at pH 6.0 [28]. Until now, only a study of Miglionico et al. could show increased cellular senescence in HepG2 cells carrying an ABCC6 knockdown [18]. In this study, we were now able to detect a significant increase in SA- $\beta$-Gal activity in primary human dermal fibroblasts of PXE patients in vitro, which potentially indicates a direct influence of $A B C C 6$ deficiency on affected peripheral tissues supporting the cellular hypothesis of PXE pathomechanism. As SA- $\beta$-Gal is lysosomal $\beta$-Gal, several studies refer to increased SA- $\beta$-Gal activity to an increased lysosomal protein concentration or activity of $\beta$-galactosidase or to an accumulation of lysosomes [29,30]. Therefore, we detected protein levels of LAMP1, a ubiquitous lysosomal membrane protein, to evaluate a possible accumulation of lysosomes. As we could not detect significant differences in LAMP1 between PXE fibroblasts and NHDF neither in medium with 10\% FCS nor in medium with $10 \%$ LPDS, the increased SA- $\beta$-Gal activity in PXE fibroblasts is, therefore, probably not associated with an accumulation of lysosomes, but with increased lysosomal activity or an increased $\beta$-galactosidase protein concentration within the lysosomes. Apart from this, we observed a decreased SA- $\beta$-Gal activity in PXE fibroblasts when cultivated in 10\% LPDS compared to PXE fibroblasts cultivated in 10\% FCS, but an increase in LAMP1 on the application of $10 \%$ LPDS compared to the cultivation in 10\% FCS. This shows that the withdrawal of lipoproteins results in an accumulation of lysosomes to probably control energy balance, but the SA- $\beta$-Gal protein is less active on lipoprotein depletion, although the reason for this remains unclear.

Apart from an increase in SA- $\beta$-Gal activity, cellular senescence is also associated with a loss in lamin B1 expression [21-23]. In this study, no significant differences in LMNB1 mRNA-expression between PXE fibroblasts and NHDF were detected when cultivated in 10\% FCS. However, under lipoprotein depleted conditions, a significant decrease of LMNB1 gene expression was measured for PXE fibroblasts compared to NHDF under the same conditions as wells as compared to PXE fibroblasts cultivated in 10\% FCS. A previous study showed that the loss of lamin B1 is associated with the stimulation of $\mathrm{p} 53$ and the pRB [21]. Thus, lamin B1 expression is controlled by the transcription factor E2F, which is bound to hypophosphorylated pRB. Phosphorylation of pRB by different cyclin-dependent kinases (CDK) leads to E2F release and initiation of LMNB1 expression. CDKs are controlled by different CDKI, which suppress pRB phosphorylation and, thus, the release of E2F. If pRB remains hypophosphorylated because of CDK inhibition, the result is a permanent cell cycle arrest and a reduction in E2F-dependent proteins like lamin B1 [22,24,25]. For PXE fibroblasts, we found no significant changes in E2F or cyclin protein level compared to NHDF when cultivated in 10\% LPDS. However, we found a significant increase in $p 21$ gene expression for PXE fibroblasts compared to NHDF when cultivated in 10\% FCS as well as in 10\% LPDS. No simultaneous induction of $p 53$ gene expression was observed in PXE fibroblasts, which leads to the assumption of a p53-independent p21-mediated 
mechanism for the induction of cellular senescence in PXE fibroblasts. Additionally, the stable $p 53$ gene expression raises the question of whether the reduction in LMNB1 mRNA-expression seen for PXE fibroblasts is directly dependent on the p53/pRB pathway. It could be, thus, rather a result of the lack of lipoproteins by cultivation in 10\% LPDS as lamin B1 maturation is strongly dependent on prenylation processes, which are themselves dependent on cholesterol biosynthesis [31]. Previous studies showed that cholesterol biosynthesis is strongly induced in PXE fibroblasts, especially when cultivated in $10 \%$ LPDS [20]. $p 21$ could be further upregulated by binding of the transcription factors signal transducer and activator of transcription (STAT) 1 or STAT3 in a p53-independent manner [32]. STAT3 is part of the Janus kinase (JAK)-STAT signal pathway that can be activated by small GTPases, which are in turn dependent on prenylation processes as well [33-37]. Nevertheless, we found no significant increase in p21 protein level, which raises the question of whether p21 is indeed the trigger of cellular senescence in PXE fibroblasts. In contrast to $p 21$, we detected a significant decrease in $p 27$ gene expression for PXE fibroblasts in both media. An increased $p 27$ gene expression is associated with a temporary proliferation arrest due to contact inhibition [38,39]. As PXE fibroblasts show increased cellular senescence compared to NHDF cell-cell contact and, thus, cell density in cultures of PXE fibroblasts is probably lower. Consequently, induction of $p 27$ gene expression could probably not be detected for PXE fibroblasts.

However, another well-known characteristic of senescent cells is the expression and secretion of a SASP. We recently showed aberrant gene expression of the secreted proteins insulin-like growth factor-binding protein 3 (IGFBP3) as well as growth differentiation factor 11 for PXE fibroblasts indicating alterations of the secretome probably due to premature aging. In the same study, we additionally have seen a clear sexual dimorphism with decreased IGFBP3 expression in PXE fibroblasts from male donors and no differences in PXE fibroblasts from female donors compared to the appropriate control fibroblasts [40]. Here, we detected a drastically increased IL6 mRNA-expression as well as IL6 protein concentration in cell culture supernatants for PXE fibroblasts compared to NHDF when cultivated in medium with $10 \%$ FCS as well as in medium with $10 \%$ LPDS. However, we did not see a considerable significant sexual dimorphism either for IL6 or for any of the other tested targets in this study. This indicates that the previously observed sexual dimorphism probably only applies to specific factors in the case of PXE. Nevertheless, IL6 is a prominent component of a SASP, and it is known that IL6 can also activate STAT3 and, therefore, induce the JAK-STAT signal pathway. As a consequence, IL6 may stimulate its own expression in an autocrine manner and potentially participates in the induction of p21 expression and, thus, cellular senescence [32,36,41]. We further detected an increase in $M C P 1$ gene expression and MCP1 protein concentration in supernatants of PXE fibroblasts compared to NHDF in both media. Several previous studies already showed that IL6 could stimulate MCP1 expression in various cell types [42-44]. It was further shown that MCP1 could stimulate the $\beta$-galactosidase activity and expression of CDK inhibitors in human keratinocytes [45], which matches the present results and indicates a potential paracrine effect that may trigger cellular senescence in PXE fibroblasts. Besides MCP1, previous studies showed that IL6 can also stimulate ICAM1 expression and secretion and that gene expression of ICAM1 is increased in senescent fibroblasts [46,47]. It is further known that increased concentrations of ICAM1 can be found in the serum of PXE patients as wells as in supernatants of $A B C C 6$ deficient $\mathrm{C} 3 \mathrm{H}$ macrophages [48,49]. Although we detected a strong increase in IL6 gene expression and protein concentration in supernatants of PXE fibroblasts, we did not see any significant increase in ICAM1 gene expression. A previous study further showed that induction of ICAM1 expression is associated with an increase in p53 [50], which would explain the missing upregulation of ICAM1 in the case of PXE fibroblasts.

This is the first study linking an $A B C C 6$ deficiency in primary human dermal fibroblasts of PXE patients to premature cellular senescence. The suggested altered cellular pathways and their potential connection in PXE are summarized in Figure 5. The further data point to a p21-triggered mechanism for the initiation of cellular senescence and the development of a proinflammatory SASP with drastically increased IL6 expression and secretion for PXE fibroblasts. However, because of 
potential high interindividual variability of factors like IL6 [51,52], further studies, e.g., with control fibroblasts from far older individuals or control fibroblasts of high passages with increased replicative senescence, need to be done to be able to better relate the severity of the PXE phenotype detected in this study to an actually aged phenotype. Additionally, studies to evaluate potentially involved mechanisms like the JAK-STAT signal pathway would give further insights into PXE pathomechanism.

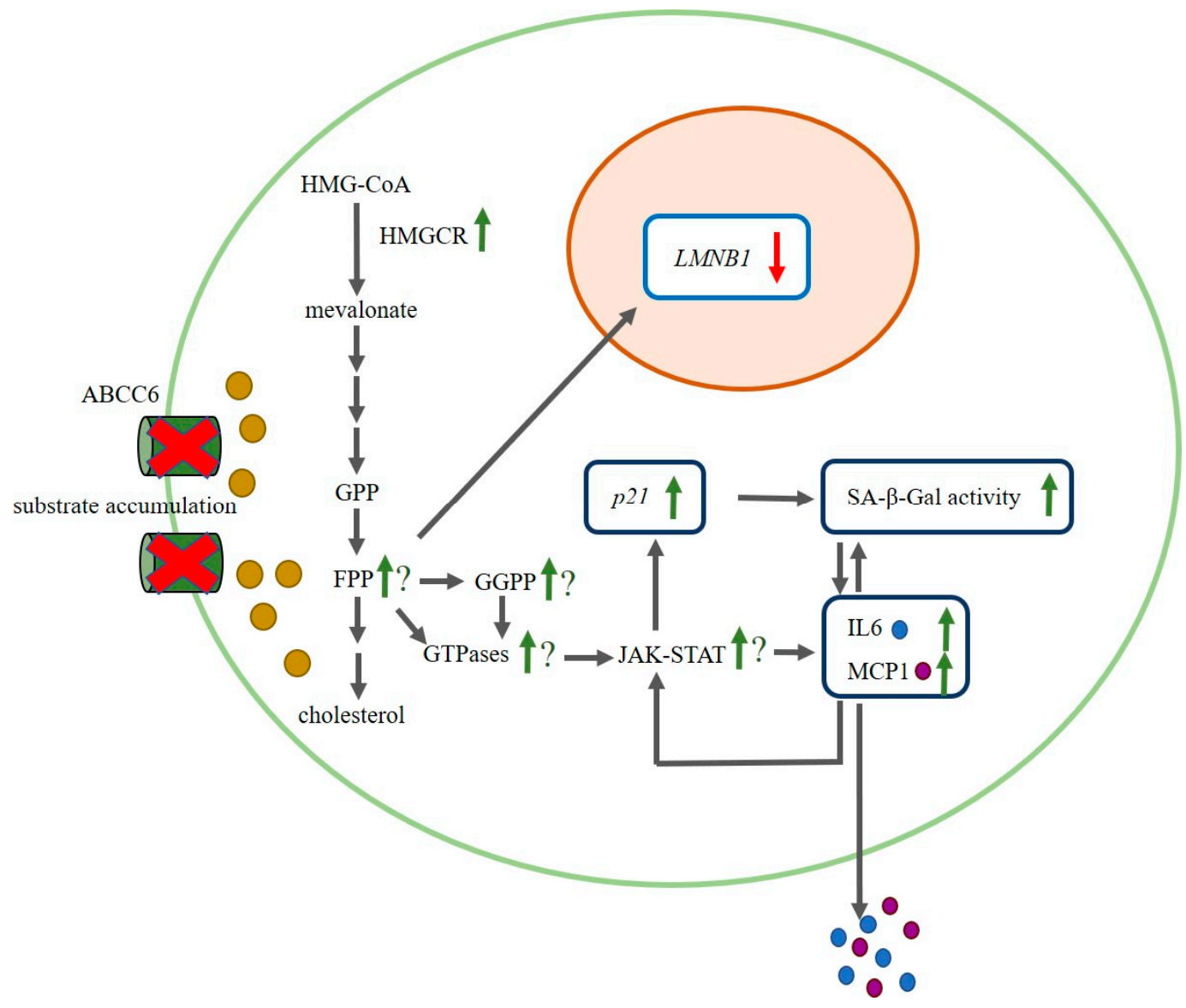

Figure 5. Suggested altered cellular pathways and their potential connection in PXE. The induction of cholesterol biosynthesis could lead to an increase in prenylation of small GTPases. Small GTPases are responsible for the activation of STAT3 and the Janus kinase (JAK)-STAT signal pathway. STAT3 could, thus, further upregulate p21, which in turn could induce cellular senescence and SA- $\beta$-Gal activity. Due to the development of a proinflammatory SASP, IL6 and MCP1 expression would increase and could further contribute to the induction of STAT3 and the JAK-STAT signal pathway. In addition to this, the induction of the cholesterol biosynthesis could lead to a reduction of $L M N B 1$ gene expression under lipoprotein depleted conditions as a compensatory effect $A B C C 6$ : ATP-binding cassette sub-family C member 6; FPP: farnesylpyrophosphate; GPP: geranylpyrophasphate; GGPP: geranylgeranylpyrophosphate; HMG-CoA: 3-hydroxy-3-methyl-glutaryl-coenzyme A; HMGCR: 3-hydroxy-3-methyl-glutaryl-coenzyme A reductase; IL6: interleukin 6; JAK-STAT: Janus kinase-signal transducer and activator of transcription; LMNB1: lamin B1; MCP1: monocyte chemoattractant protein-1; SA- $\beta$-Gal activity: senescence-associated- $\beta$-galactosidase activity.

\section{Materials and Methods}

\subsection{Experimental Design}

The study was designed to evaluate potential premature aging processes in PXE on a cellular level using primary human dermal fibroblasts of PXE patients and healthy controls. Thus, fibroblasts were cultured in a medium supplemented with either 10\% FCS or 10\% LPDS. As previous studies showed 
that the cholesterol biosynthesis might play a crucial role in PXE pathogenesis [20], LPDS was used to reveal effects that would be otherwise maybe covert by an excess of exogenous lipoproteins applied by conventional FCS. Premature aging processes in PXE fibroblasts were determined by evaluating the SA- $\beta$-Gal activity and LAMP1 protein level as wells as LMNB1 gene and lamin B1 protein level. Furthermore, $p 27, p 53$, as well as $p 21$ mRNA-expression, were examined. Additionally, protein expression of several factors of the cell cycle control was determined by a Cell Cycle Antibody Array. As senescent cells are characterized by a proinflammatory secretory phenotype, gene expression and protein concentrations in cell culture supernatants of factors like IL6, MCP1, as well as ICAM1 were measured.

\subsection{Cell Culture}

NHDF were purchased from Coriell Institute for Medical Research (Camden, NJ, USA). Dermal fibroblasts from PXE patients were isolated from skin biopsies [53]. Information about fibroblasts characteristics with the appropriate available Phenodex scores, according to Legrand et al. [3], are listed in Table 2. All patients and controls gave their informed consent for participation in the study. The study was conducted in accordance with the Declaration of Helsinki and approved by the Ethics Committee of the HDZ NRW, Department of Medicine, Ruhr University of Bochum (registry no. 32/2008, Approval date is 3 November 2008).

Table 2. Characteristics of fibroblasts used.

\begin{tabular}{|c|c|c|c|c|c|c|c|}
\hline $\begin{array}{l}\text { Sample } \\
\text { ID }\end{array}$ & Gender & Age $^{1}$ & $\begin{array}{l}\text { Biopsy } \\
\text { Source }\end{array}$ & \multicolumn{2}{|c|}{ ABCC6 Genotype ${ }^{2}$} & $\begin{array}{l}\text { Genotype } \\
\text { Status }\end{array}$ & $\begin{array}{c}\text { Phenodex } \\
\text { Score }^{3}\end{array}$ \\
\hline \multicolumn{8}{|c|}{ PXE patients } \\
\hline P3M ${ }^{a}$ & male & 57 & Neck & $\begin{array}{l}\text { c. } 3421 C>T \\
(\text { p.Arg1141*) }\end{array}$ & $\begin{array}{l}\text { c.3883-6G >A } \\
(\mathrm{SSM})\end{array}$ & cht & $\mathrm{V} 2 ; \mathrm{C} 0$ \\
\hline $\mathrm{P} 128 \mathrm{M}^{\mathrm{a}}$ & male & 51 & Neck & $\begin{array}{l}\text { c.3769_3770insC } \\
\text { (p.L1259fsX1277) }\end{array}$ & $\begin{array}{l}\text { c.3769_3770insC } \\
\text { (p.L1259fsX1277) }\end{array}$ & $\mathrm{hm}$ & $\begin{array}{l}\text { S2; E2; G0; } \\
\text { C1 }\end{array}$ \\
\hline $\mathrm{P} 255 \mathrm{~F}^{\mathrm{a}}$ & female & 48 & Arm & $\begin{array}{l}\text { c. } 3421 C>T \\
(\text { p.Arg1141*) }\end{array}$ & c. $2787+1 \mathrm{G}>\mathrm{T}$ & cht & $\begin{array}{l}\text { S3; E2; G0; } \\
\text { C0 }\end{array}$ \\
\hline \multicolumn{8}{|c|}{ Healthy controls } \\
\hline $\begin{array}{l}\text { M57A }^{\mathrm{b}} \\
\text { (AG13145) }\end{array}$ & male & 57 & Arm & - & - & wt & $\begin{array}{l}\text { Not } \\
\text { applicable }\end{array}$ \\
\hline $\begin{array}{c}\text { M52A }^{\mathrm{b}} \\
(\mathrm{AG} 11482)\end{array}$ & male & 52 & Arm & - & - & wt & $\begin{array}{l}\text { Not } \\
\text { applicable }\end{array}$ \\
\hline $\begin{array}{c}\text { F48A }{ }^{\mathrm{b}} \\
(\mathrm{AG} 14284)\end{array}$ & female & 48 & Arm & - & - & wt & $\begin{array}{l}\text { Not } \\
\text { applicable }\end{array}$ \\
\hline
\end{tabular}

hm, homozygous; cht, compound heterozygous; wt, wild type; SSM, splice site mutation a Fibroblasts isolated from skin biopsies [53]. ${ }^{\mathrm{b}}$ Fibroblasts purchased from Coriell Institute for Medical Research (Camden, NJ, USA). ${ }^{1}$ Age in years. ${ }^{2}$ Nucleotide numbering refers to the cDNA sequence with the A of the ATG translation initiation start site as nucleotide +1 (GenBank accession number NM_001171.2). ${ }^{3}$ adapted from the Phenodex score (an internationally standardized scoring system for uniform evaluation of PXE cases) according to Legrand et al. [3]. S: skin; E: eye; G; gastrointestinal; V: vascular; C: cardiac.

Fibroblasts were cultivated in Dulbecco's modified essential medium (DMEM, Gibco, Thermo Fisher Scientific, Waltham, MA, USA) supplemented with 10\% FCS (Biowest Nuaillé, France), $2 \%$ L-glutamine (200 mM) (PAN Biotech, Aidenbach, Germany) and 1\% antibiotic/antimycotic solution (PAA Laboratories, Pasching, Austria). When reaching confluency, fibroblasts were subcultured.

Fibroblasts between passages 9 and 12 were used. Biological samples were prepared in triplicates. For all experiments, cells were seeded in a final cell density of $177 \mathrm{cells} / \mathrm{mm}^{2}$. Fibroblasts were cultivated for $24 \mathrm{~h}$ in $10 \%$ FCS. The next day, the medium was changed to fresh $10 \%$ FCS or $10 \%$ LPDS for an additional $24 \mathrm{~h}, 72 \mathrm{~h}$ or 21 days. In the case of 21 days, the medium was changed every 2-3 days.

\subsection{Delipidation of FCS}

LPDS was prepared, according to Gibson et al. [54]. $1 \mathrm{~g}$ Cab-o-sil (silicic acid powder) was mixed with $50 \mathrm{~mL}$ FCS and incubated at $4{ }^{\circ} \mathrm{C}$ overnight. The next day, the mixture was centrifuged for 
$1 \mathrm{~h}$ at $4{ }^{\circ} \mathrm{C}$, and $5000 \times g$ and the clarified supernatant was transferred to a new tube and stored at $-20^{\circ} \mathrm{C}$. For the preparation of fresh medium, LPDS was sterile filtered $(0.2 \mu \mathrm{m})$. After delipidation, free cholesterol is reduced by about $78 \%$, LDL by about $95 \%$ and HDL by about $57 \%$, whereas triglyceride concentrations remained unchanged.

\subsection{Nucleic Acid Isolation}

For RNA isolation, the NucleoSpin RNA Kit (Macherey-Nagel, Düren, Germany) was used. DNA isolation for normalization of immunoassay measurements was performed using the NucleoSpin Blood extraction Kit (Macherey-Nagel, Düren, Germany). Procedures were performed according to the manufacturer's instructions.

\subsection{Bicinchoninic Acid Assay}

Bicinchoninic acid (BCA) assay was performed for the determination of protein concentration in cell lysates. For analysis, $25 \mu \mathrm{L}$ cell lysate was mixed with $200 \mu \mathrm{L}$ copper (II) sulfate solution/ bicinchoninic acid (1:50). A standard curve was prepared using a serial dilution of bovine serum albumin (stock: $1 \mathrm{mg} / \mathrm{mL}$ ). The reaction mixture was incubated for $30 \mathrm{~min}$ at $37^{\circ} \mathrm{C}$. Absorption was measured at $562 \mathrm{~nm}$ using a Tecan Reader infinite 200 Pro (Tecan, Männedorf, Switzerland). Protein concentrations were used for the normalization of quantitative $\beta$-galactosidase activity measurements.

\subsection{Gene Expression Analysis}

For cDNA synthesis, $1 \mu \mathrm{g}$ RNA was transcribed into cDNA using SuperScript II Reverse Transcriptase (Thermo Fisher Scientific, Waltham, MA, USA). For p27, p53, p21, LMNB1, IL6, MCP1 and ICAM1 $2.5 \mu \mathrm{L}$ cDNA (1:10), $0.25 \mu \mathrm{L}$ forward and reverse primer (Biomers, Ulm, Germany), $2.0 \mu \mathrm{L}$ water and $5.0 \mu \mathrm{L}$ LightCycler 480 SYBR Green I Master reaction mixture (Roche, Penzberg, Germany) was mixed for each measurement. After an initial incubation for $5 \mathrm{~min}$ at $95^{\circ} \mathrm{C}$, the qPCR protocol involves 45 cycles of denaturation $\left(95^{\circ} \mathrm{C}, 10 \mathrm{~s}\right.$ ), annealing (specific annealing temperature, $15 \mathrm{~s})$ and elongation $\left(72{ }^{\circ} \mathrm{C}, 20 \mathrm{~s}\right)$. Relative mRNA expression of measured targets was normalized to relative $\beta$-actin ( $\beta$-ACTIN), glyceraldehyde-3-phosphate-dehydrogenase (GAPDH) and $\beta 2$-microglobulin ( $\beta 2 M)$ mRNA expression. After amplification, melting curve analysis was performed. Measurements of gene expression were conducted using LightCycler 480 (Roche, Penzberg, Germany). Relative mRNA expression was calculated using the delta-delta Ct method considering PCR efficiency. Technical triplicates were done for each biological sample. Sequences of forward and reverse primers can be found in Table 3 .

\subsection{Immunofluorescence Microscopy}

For immunofluorescence experiments, coverslips $(\varnothing 18 \mathrm{~mm})$ were placed into a 12-well plate and coated with $5 \mu \mathrm{g} / \mathrm{cm}^{2}$ rat collagen (ibidi, Gräfelfing, Germany). Fibroblasts were seeded with the previously stated cell density and incubated for $24 \mathrm{~h}$ in $10 \%$ FCS. Afterward, the medium was changed by fresh $10 \%$ FCS or 10\% LPDS for a further $72 \mathrm{~h}$. 
Table 3. Primer sequences used for quantitative real-time PCR.

\begin{tabular}{|c|c|c|c|c|c|}
\hline Gene & Protein & $5^{\prime}-3^{\prime}$ Sequence & Reference $^{1}$ & $\begin{array}{c}\text { Annealing } \\
\text { Temperature } \\
\left({ }^{\circ} \mathrm{C}\right)\end{array}$ & Efficiency \\
\hline $\begin{array}{l}\beta \text {-ACTIN } \\
\text { beta-Actin } \\
\text { GAPDH }\end{array}$ & $\beta$-Actin & $\begin{array}{l}\text { CGCGAGAAGATGACCC } \\
\text { ATTGCCAATGGTGATGAC }\end{array}$ & NM_001101 & 59 & 2.0 \\
\hline $\begin{array}{l}\text { glycerinaldehyd } \\
\text {-3-phosphat- } \\
\text { dehydrogenase }\end{array}$ & GAPDH & $\begin{array}{l}\text { AGGTCGGAGTCAACGGAT } \\
\text { TCCTGGAAGATGGTGATG }\end{array}$ & NM_002046 & 59 & 1.8 \\
\hline $\begin{array}{c}\beta 2 M \\
\text { beta-2- } \\
\text { microglobulin } \\
\text { ICAM1 }\end{array}$ & $\beta 2 \mathrm{M}$ & $\begin{array}{l}\text { TGTGCTCGCGCTACTCTCTCTT } \\
\text { CGGATGGATGAAACCCAGACA }\end{array}$ & NM_004048 & 59 & 2.0 \\
\hline $\begin{array}{l}\text { Intercellular } \\
\text { adhesion } \\
\text { molecule } 1\end{array}$ & ICAM1 & $\begin{array}{l}\text { ACCATCTACAGCTTTCCGGC } \\
\text { CAATCCCTCTCGTCCAGTCG }\end{array}$ & NM_000201.3 & 63 & 1.9 \\
\hline $\begin{array}{c}\text { IL6 } \\
\text { Interleukin } 6\end{array}$ & IL6 & $\begin{array}{l}\text { ACAGCCACTCACCTCTTCAG } \\
\text { GTGCCTCTTTGCTGCTTTCAC }\end{array}$ & NM 000600.4 & 63 & 1.9 \\
\hline $\begin{array}{l}\text { LMNB1 } \\
\text { Lamin B1 } \\
\text { MCP1 }\end{array}$ & Lamin B1 & $\begin{array}{l}\text { GCAGACTTACCATGCCAAAC } \\
\text { TCCCTTATTTCCGCCATCTC }\end{array}$ & NM 005573.3 & 63 & 1.9 \\
\hline $\begin{array}{l}\text { Monocyte } \\
\text { chemotactic } \\
\text { Protein } 1\end{array}$ & MCP1 & $\begin{array}{l}\text { CTTCTGTGCCTGCTGCTCATA } \\
\text { GGACACTTGTCGCTGGTGATT }\end{array}$ & NM 002982.3 & 66 & 2.0 \\
\hline $\begin{array}{l}\text { p21/CDKN1A } \\
\text { cyclin-dependent } \\
\quad \text { kinase } \\
\text { inhibitor } 1 A \\
\text { p27/CDKN1B }\end{array}$ & p21 & $\begin{array}{l}\text { GCAGACCAGCATGACAGATTTC } \\
\text { ACCTCCGGGAGAGAGGAAAA }\end{array}$ & NM_000389.4 & 66 & 1.8 \\
\hline $\begin{array}{l}\text { Cyclin-dependent } \\
\text { kinase } \\
\text { inhibitor } 1 B\end{array}$ & p27 & $\begin{array}{l}\text { CAGCTTGCCCGAGTTCTACT } \\
\text { AGAAGAATCGTCGGTTGCAGG }\end{array}$ & NM_004064.4 & 66 & 2.0 \\
\hline $\begin{array}{c}\text { p53 } \\
\text { tumor } \\
\text { protein p53 }\end{array}$ & p53 & $\begin{array}{l}\text { AGATAGCGATGGTCTGGC } \\
\text { TTGGGCAGTGCTCGCTTAGT }\end{array}$ & NM_000546.5 & 63 & 2.0 \\
\hline
\end{tabular}

After the stated time of cultivation, fibroblasts were washed with phosphate-buffered saline (PBS; Gibco, Thermo Fisher Scientific, Waltham, MA, USA). Fixation and permeabilization of cells were done by incubating with acetone:methanol (1:1) for $10 \mathrm{~min}$ at room temperature. Afterward, cells were washed again twice with PBS and incubated for $1 \mathrm{~h}$ in $1 \%$ bovine serum albumin (BSA) diluted in PBS to block unspecific binding sites. After two further washing steps, fibroblasts were incubated with primary antibodies for $2 \mathrm{~h}$ at room temperature. Primary antibodies used included rabbit anti-lamin B1 (ab16046; Abcam (Cambridge, UK); 1:1000) and mouse anti-LAMP1 (ab25630; Abcam (Cambridge, UK); 1:50). After another two washes, fibroblasts were incubated for $1 \mathrm{~h}$ with the secondary antibody at room temperature under the exclusion of light. For the secondary antibody, a FITC-conjugated goat anti-rabbit (1:75) (Jackson Immuno Research, West Grove, PA, USA) was used. Antibodies were diluted in $0.1 \%$ BSA in PBS. Fibroblasts were washed again twice and were counterstained with DAPI. The counterstaining was followed by another three washes with PBS. Coverslips were mounted with ProLong Diamond Antifade Mountant (Thermo Fisher Scientific, Waltham, MA, USA). Immunofluorescence images were captured by fluorescence microscopy using the microscope TE2000-S (Nikon GmbH, Düsseldorf, Germany) or confocal laser scanning microscopy TCS SP8 system (Leica Microsystems, Wetzlar, Germany). For confocal laser scanning microscopy, FITC was excited at $488 \mathrm{~nm}$, and emission was detected between 493 and $557 \mathrm{~nm}$. 


\subsection{Qualitative Senescence Assay}

For the evaluation of the number of senescent fibroblasts in culture, the $\beta$-galactosidase activity was determined, according to Dimri et al. [28]. In brief, fibroblasts were seeded as previously stated in 6-well plates and cultivated in $10 \% \mathrm{FCS}$ for $24 \mathrm{~h}$. Afterward, the medium was replaced by either medium supplemented with $10 \%$ FCS or $10 \%$ LPDS and cultivated for another $72 \mathrm{~h}$. After the stated time of growth, the medium was removed, and fibroblasts were washed twice with PBS. Fibroblasts were fixed with $2 \mathrm{~mL} \mathrm{3 \%}$ formaldehyde for 3-5 min at room temperature. Afterward, two further washing steps were performed and followed by application of the substrate solution $(0.2 \mathrm{M}$ sodium phosphate, $0.1 \mathrm{M}$ citric acid, $5 \mathrm{mM}$ potassium ferrocyanide (trihydrate), $5 \mathrm{mM}$ potassium ferrocyanide, $150 \mathrm{mM}$ $\mathrm{NaCl}$, two $\mathrm{mM} \mathrm{MgCl}_{2}$ (hexahydrate), $1 \mathrm{mg} / \mathrm{mL}$ 5-bromo-4-chloro-3-indolyl- $\beta$-D-galactopyranoside, $\mathrm{pH}$ 6.0). Fibroblasts were incubated overnight at $37^{\circ} \mathrm{C}$ without $\mathrm{CO}_{2}$. The next day, images were captured using the microscope TE2000-S (Nikon GmbH, Düsseldorf, Germany).

\subsection{Quantitative Senescence Assay}

Quantitative determination of $\beta$-galactosidase activity was conducted according to a previous protocol of Gary and Kindell [55]. In brief, fibroblasts were seeded according to previously mentioned instructions in $60 \mathrm{~mm}$ cell culture dishes and incubated for $24 \mathrm{~h}$ in $10 \%$ FCS. Afterward, the medium was changed with fresh medium with $10 \%$ FCS or 10\% LPDS and fibroblasts were cultivated for another $72 \mathrm{~h}$. After this, the medium was removed, and fibroblasts were washed four times with PBS. $300 \mu \mathrm{L}$ lysis buffer $(0.2 \mathrm{M}$ sodium phosphate, $0.1 \mathrm{M}$ citric acid, $5 \mathrm{mM}$ CHAPS, $0.5 \mathrm{mM}$ benzamidine, 0.25 mM PMSF, pH 6.0) was applied onto the cell layer and fibroblasts were detached using a cell scraper. Lysates were centrifuged for $5 \mathrm{~min}$ at $12,000 \times \mathrm{g}$. $50 \mu \mathrm{L}$ of the clarified supernatant was used for the BCA assay. $100 \mu \mathrm{L}$ of the supernatant was mixed with $100 \mu \mathrm{L}$ of reaction buffer $(0.2 \mathrm{M}$ sodium phosphate, $0.1 \mathrm{M}$ citric acid, $300 \mathrm{mM} \mathrm{NaCl}, 10 \mathrm{mM} \beta$-mercaptoethanol, $4 \mathrm{mM} \mathrm{MgCl} 2,1.7 \mathrm{mM}$ 4-methylumbelliferyl- $\beta$-D-galactopyranoside, $\mathrm{pH}$ 6.0) and incubated for $1 \mathrm{~h}$ at $37^{\circ} \mathrm{C}$. After incubation, $50 \mu \mathrm{L}$ of the reaction mixture was added to $150 \mu \mathrm{L}$ of a $400 \mathrm{mM}$ sodium carbonate solution to stop the reaction. $150 \mu \mathrm{L}$ of the mixture was added to a black 96-well plate and measured using a Tecan Reader Infinite 200 PRO (excitation: $360 \mathrm{~nm}$, emission: $465 \mathrm{~nm}$ ). Results were normalized to protein concentrations of cell lysates.

\subsection{Immunoassays for Evaluation of SASP Factors in Cell Culture Supernatants}

For the determination of protein concentrations of MCP1 as well as ICAM1 in cell culture supernatants, commercially available ELISA Kits (R\&D Systems, Abingdon, UK) were used. Measurements of IL6 concentrations in cell culture supernatants were conducted using the immunoanalyzer Cobas e411 (Roche, Basel, Switzerland). Results were normalized to DNA content.

\subsection{Cell Cycle Antibody Array}

For the antibody array (Full Moon BioSystems, Sunnyvale, CA, USA), cells were seeded in $60 \mathrm{~mm}$ cell culture dishes with the previously stated cell density and incubated for $24 \mathrm{~h}$ in $10 \%$ FCS. To achieve the required protein concentration, eight biological replicates were performed. The next day, the medium was changed to $10 \%$ LDPS and cells were cultivated for a further $72 \mathrm{~h}$. After the stated time of growth, cells were washed four times with PBS, and $150 \mu \mathrm{L}$ RIPA buffer (Thermo Fisher, Waltham, MA, USA) was applied to the first of the eight biological replicates. Cells were detached using a cell scraper. The cell lysate of the first biological replicate was afterward transferred to the second biological replicate, and cells were again detached with a cell scraper before the whole cell lysate is transferred to the third biological replicate. The procedure was repeated until the eighth biological replicate. The protein concentrations of the resulting cell lysates were determined by BCA assay. Afterward, all cell lysates were diluted to a concentration of $3 \mathrm{mg} / \mathrm{mL}$. Cell lysates of PXE fibroblasts were mixed, and cell lysates of NHDF were mixed. The cell cycle antibody array was conducted by the manufacturer 
according to their instructions for both samples. In brief, proteins were biotinylated by incubation of the cell lysates with a biotin/DMF solution $(10 \mu \mathrm{g} / \mu \mathrm{L})$ for $2 \mathrm{~h}$ at room temperature. Antibody array slides were incubated with blocking solution for $40 \mathrm{~min}$ at room temperature to block unspecific binding sides. Afterward, the blocking solution was removed. Each biotinylated protein sample was applied onto one antibody array slide and was incubated for $2 \mathrm{~h}$ at room temperature. After incubation, slides were washed several times with deionized water and incubated with a Cy3-streptavidin solution $(1 \mathrm{mg} / \mathrm{mL})$ for $45 \mathrm{~min}$ at room temperature under the exclusion of light. After several washing steps, the detection was performed with an array scanner.

\subsection{Statistical Analysis}

Data of gene expression analyses and protein concentrations in cell culture supernatants are shown as mean \pm standard error (SEM). As a statistical software GraphPad Prism 5.0 (GraphPad, San Diego, CA, USA) was used. For analyses, the nonparametric two-tailed Mann-Whitney U test was performed. $p$-values of 0.05 or less were considered statistically significant.

Author Contributions: Conceptualization, I.F., C.K. and D.H.; data curation, J.T.; formal analysis, J.T.; funding acquisition, D.H.; investigation, J.T., T.W., C.L. and R.P.; methodology, J.T., T.W. and C.L.; project administration, I.F. and D.H.; resources, I.F., C.K. and D.H.; supervision, C.K.; validation, J.T., T.W., C.L. and R.P.; visualization, J.T.; writing—original draft, J.T.; writing—review and editing, T.W., C.L., R.P., I.F., C.K. and D.H.; All authors have read and agreed to the published version of the manuscript.

Funding: This research was funded by a FORUM research grant (K107-16) of the Ruhr-University Bochum.

Acknowledgments: We thank Christoph Lichtenberg for his excellent technical assistance. We are grateful to all the PXE patients and their relatives and the Selbsthilfegruppe für PXE Erkrankte Deutschlands e. V.

Conflicts of Interest: The authors declare no conflict of interest.

\section{Abbreviations}

$\begin{array}{ll}\text { ABCC6 } & \text { ATP-binding cassette sub-family C member } 6 \\ \text { CDK } & \text { Cyclin-dependent kinase } \\ \text { CDKI } & \text { Cyclin-dependent kinase inhibitor } \\ \text { FCS } & \text { Fetal calf serum } \\ \text { HGPS } & \text { Hutchinson-Gilford progeria syndrome } \\ \text { ICAM1 } & \text { Intercellular adhesion molecule 1 } \\ \text { IL6 } & \text { Interleukin 6 } \\ \text { JAK } & \text { Janus Kinase } \\ \text { LAMP1 } & \text { Lysosomal-associated membrane protein 1 } \\ \text { LMNB1 } & \text { Lamin B1 } \\ \text { LPDS } & \text { Lipoprotein-deficient fetal calf serum } \\ \text { MCP1 } & \text { Monocyte chemoattractant protein-1 } \\ \text { MMP } & \text { Matrix metalloproteinase } \\ \text { NHDF } & \text { Normal human dermal fibroblasts } \\ \text { PPi } & \text { Pyrophosphate } \\ \text { pRB } & \text { Retinoblastoma protein } \\ \text { PXE } & \text { Pseudoxanthoma elasticum } \\ \text { SA- } \beta-\text { Gal } & \text { Senescence-associated } \beta \text {-galactosidase } \\ \text { SASP } & \text { Senescence-associated secretory phenotype } \\ \text { STAT } & \text { Signal transducer and activator of transcription }\end{array}$

\section{References}

1. Germain, D.P. Pseudoxanthoma elasticum. Orphanet J. Rare Dis. 2017, 12, 85. [CrossRef] [PubMed]

2. Le Saux, O.; Urban, Z.; Tschuch, C.; Csiszar, K.; Bacchelli, B.; Quaglino, D.; Pasquali-Ronchetti, I.; Pope, F.M.; Richards, A.; Terry, S.; et al. Mutations in a gene encoding an ABC transporter cause pseudoxanthoma elasticum. Nat. Genet. 2000, 25, 223-227. [CrossRef] [PubMed] 
3. Legrand, A.; Cornez, L.; Samkari, W.; Mazzella, J.-M.; Venisse, A.; Boccio, V.; Auribault, K.; Keren, B.; Benistan, K.; Germain, D.P.; et al. Mutation spectrum in the ABCC6 gene and genotype-phenotype correlations in a French cohort with pseudoxanthoma elasticum. Genet. Med. 2017, 19, 909-917. [CrossRef] [PubMed]

4. Ronchetti, I.; Boraldi, F.; Annovi, G.; Cianciulli, P.; Quaglino, D. Fibroblast involvement in soft connective tissue calcification. Front. Genet. 2013, 4. [CrossRef]

5. Boraldi, F.; Annovi, G.; Vermeer, C.; Schurgers, L.J.; Trenti, T.; Tiozzo, R.; Guerra, D.; Quaglino, D. Matrix gla protein and alkaline phosphatase are differently modulated in human dermal fibroblasts from PXE patients and controls. J. Investig. Dermatol. 2013, 133, 946-954. [CrossRef]

6. Boraldi, F.; Annovi, G.; Bartolomeo, A.; Quaglino, D. Fibroblasts from patients affected by Pseudoxanthoma elasticum exhibit an altered PPi metabolism and are more responsive to pro-calcifying stimuli. J. Dermatol. Sci. 2014, 74, 72-80. [CrossRef]

7. Villa-Bellosta, R.; Rivera-Torres, J.; Osorio, F.G.; Acín-Pérez, R.; Enriquez, J.A.; López-Otín, C.; Andrés, V. Defective extracellular pyrophosphate metabolism promotes vascular calcification in a mouse model of Hutchinson-Gilford progeria syndrome that is ameliorated on pyrophosphate treatment. Circulation 2013, 127, 2442-2451. [CrossRef]

8. Guo, H.; Li, Q.; Chou, D.W.; Uitto, J. Atorvastatin counteracts aberrant soft tissue mineralization in a mouse model of pseudoxanthoma elasticum (Abcc6 -/-). J. Mol. Med. 2013, 91, 1177-1184. [CrossRef]

9. Li, Q.; Sundberg, J.P.; Levine, M.A.; Terry, S.F.; Uitto, J. The effects of bisphosphonates on ectopic soft tissue mineralization caused by mutations in the ABCC6 gene. Cell Cycle 2015, 14, 1082-1089. [CrossRef]

10. Luft, F.C. Pseudoxanthoma elasticum and statin prophylaxis. J. Mol. Med. 2013, 91, 1129-1130. [CrossRef]

11. Wheaton, K.; Campuzano, D.; Ma, W.; Sheinis, M.; Ho, B.; Brown, G.W.; Benchimol, S. Progerin-Induced Replication Stress Facilitates Premature Senescence in Hutchinson-Gilford Progeria Syndrome. Mol. Cell. Biol. 2017, 37. [CrossRef] [PubMed]

12. López-Otín, C.; Blasco, M.A.; Partridge, L.; Serrano, M.; Kroemer, G. The Hallmarks of Aging. Cell 2013, 153, 1194-1217. [CrossRef] [PubMed]

13. Demaria, M.; Ohtani, N.; Youssef, S.A.; Rodier, F.; Toussaint, W.; Mitchell, J.R.; Laberge, R.-M.; Vijg, J.; Van Steeg, H.; Dollé, M.E.T.; et al. An Essential Role for Senescent Cells in Optimal Wound Healing through Secretion of PDGF-AA. Dev. Cell 2014, 31, 722-733. [CrossRef] [PubMed]

14. Faust, I.; Donhauser, E.; Fischer, B.; Ibold, B.; Kuhn, J.; Knabbe, C.; Hendig, D. Characterization of dermal myofibroblast differentiation in pseudoxanthoma elasticum. Exp. Cell Res. 2017, 360, 153-162. [CrossRef]

15. Diekmann, U.; Zarbock, R.; Hendig, D.; Szliska, C.; Kleesiek, K.; Götting, C. Elevated circulating levels of matrix metalloproteinases MMP-2 and MMP-9 in pseudoxanthoma elasticum patients. J. Mol. Med. 2009, 87, 965-970. [CrossRef]

16. Chau, K.Y.; Sivaprasad, S.; Patel, N.; Donaldson, T.A.; Luthert, P.J.; Chong, N.V. Plasma levels of matrix metalloproteinase-2 and -9 (MMP-2 and MMP-9) in age-related macular degeneration. Eye 2008, 22, 855-859. [CrossRef]

17. Gliem, M.; Zaeytijd, J.D.; Finger, R.P.; Holz, F.G.; Leroy, B.P.; Charbel Issa, P. An update on the ocular phenotype in patients with pseudoxanthoma elasticum. Front. Genet. 2013, 4, 14. [CrossRef]

18. Miglionico, R.; Ostuni, A.; Armentano, M.F.; Milella, L.; Crescenzi, E.; Carmosino, M.; Bisaccia, F. ABCC6 knockdown in HepG2 cells induces a senescent-like cell phenotype. Cell. Mol. Biol. Lett. 2017, 22, 7. [CrossRef]

19. Finger, R.P.; Charbel Issa, P.; Ladewig, M.S.; Götting, C.; Szliska, C.; Scholl, H.P.N.; Holz, F.G. Pseudoxanthoma elasticum: Genetics, clinical manifestations and therapeutic approaches. Surv. Ophthalmol. 2009, 54, 272-285. [CrossRef]

20. Kuzaj, P.; Kuhn, J.; Dabisch-Ruthe, M.; Faust, I.; Götting, C.; Knabbe, C.; Hendig, D. ABCC6-A new player in cellular cholesterol and lipoprotein metabolism? Lipids Health Dis. 2014, 13, 118. [CrossRef]

21. Freund, A.; Laberge, R.-M.; Demaria, M.; Campisi, J. Lamin B1 loss is a senescence-associated biomarker. Mol. Biol. Cell 2012, 23, 2066-2075. [CrossRef] [PubMed]

22. Shimi, T.; Butin-Israeli, V.; Adam, S.A.; Hamanaka, R.B.; Goldman, A.E.; Lucas, C.A.; Shumaker, D.K.; Kosak, S.T.; Chandel, N.S.; Goldman, R.D. The role of nuclear lamin B1 in cell proliferation and senescence. Genes Dev. 2011, 25, 2579-2593. [CrossRef] 
23. Wang, A.S.; Ong, P.F.; Chojnowski, A.; Clavel, C.; Dreesen, O. Loss of lamin B1 is a biomarker to quantify cellular senescence in photoaged skin. Sci. Rep. 2017, 7, 15678. [CrossRef] [PubMed]

24. Giacinti, C.; Giordano, A. RB and cell cycle progression. Oncogene 2006, 25, 5220-5227. [CrossRef] [PubMed]

25. Weinberg, R.A. The retinoblastoma protein and cell cycle control. Cell 1995, 81, 323-330. [CrossRef]

26. Chen, Q.M.; Tu, V.C.; Catania, J.; Burton, M.; Toussaint, O.; Dilley, T. Involvement of Rb family proteins, focal adhesion proteins and protein synthesis in senescent morphogenesis induced by hydrogen peroxide. J. Cell. Sci. 2000, 113, 4087-4097.

27. Hayflick, L.; Moorhead, P.S. The serial cultivation of human diploid cell strains. Exp. Cell Res. 1961, 25, 585-621. [CrossRef]

28. Dimri, G.P.; Lee, X.; Basile, G.; Acosta, M.; Scott, G.; Roskelley, C.; Medrano, E.E.; Linskens, M.; Rubelj, I.; Pereira-Smith, O. A biomarker that identifies senescent human cells in culture and in aging skin in vivo. Proc. Natl. Acad. Sci. USA 1995, 92, 9363-9367. [CrossRef]

29. Kurz, D.J.; Decary, S.; Hong, Y.; Erusalimsky, J.D. Senescence-associated (beta)-galactosidase reflects an increase in lysosomal mass during replicative ageing of human endothelial cells. J. Cell. Sci. 2000, 113, 3613-3622.

30. Lee, B.Y.; Han, J.A.; Im, J.S.; Morrone, A.; Johung, K.; Goodwin, E.C.; Kleijer, W.J.; DiMaio, D.; Hwang, E.S. Senescence-associated $\beta$-galactosidase is lysosomal $\beta$-galactosidase. Aging Cell 2006, 5, 187-195. [CrossRef]

31. Jung, H.-J.; Nobumori, C.; Goulbourne, C.N.; Tu, Y.; Lee, J.M.; Tatar, A.; Wu, D.; Yoshinaga, Y.; de Jong, P.J.; Coffinier, C.; et al. Farnesylation of lamin B1 is important for retention of nuclear chromatin during neuronal migration. Proc. Natl. Acad. Sci. USA 2013, 110, E1923-E1932. [CrossRef] [PubMed]

32. Gartel, A.L.; Tyner, A.L. Transcriptional regulation of the p21((WAF1/CIP1)) gene. Exp. Cell Res. 1999, 246, 280-289. [CrossRef] [PubMed]

33. Das, U.N. Statins and the prevention of dementia. Can. Med. Assoc. J. 2001, 165, 908-909.

34. Magee, T.; Marshall, C. New Insights into the Interaction of Ras with the Plasma Membrane. Cell 1999, 98, 9-12. [CrossRef]

35. Molnár, G.; Dagher, M.-C.; Geiszt, M.; Settleman, J.; Ligeti, E. Role of Prenylation in the Interaction of Rho-Family Small GTPases with GTPase Activating Proteins. Biochemistry 2001, 40, 10542-10549. [CrossRef]

36. Omoigui, S. The Interleukin-6 inflammation pathway from cholesterol to aging-Role of statins, bisphosphonates and plant polyphenols in aging and age-related diseases. Immun. Ageing 2007, 4, 1. [CrossRef]

37. Pereira-Leal, J.B.; Hume, A.N.; Seabra, M.C. Prenylation of Rab GTPases: Molecular mechanisms and involvement in genetic disease. FEBS Lett. 2001, 498, 197-200. [CrossRef]

38. Dulic, V. Senescence Regulation by mTOR. In Cell Senescence; Galluzzi, L., Vitale, I., Kepp, O., Kroemer, G., Eds.; Humana Press: Totowa, NJ, USA, 2013; Volume 965, pp. 15-35.

39. Polyak, K.; Kato, J.Y.; Solomon, M.J.; Sherr, C.J.; Massague, J.; Roberts, J.M.; Koff, A. p27Kip1, a cyclin-Cdk inhibitor, links transforming growth factor-Beta and contact inhibition to cell cycle arrest. Genes Dev. 1994, 8 , 9-22. [CrossRef]

40. Tiemann, J.; Wagner, T.; Vanakker, O.M.; van Gils, M.; Cabrera, J.-L.B.; Ibold, B.; Faust, I.; Knabbe, C.; Hendig, D. Cellular and Molecular Biomarkers Indicate Premature Aging in Pseudoxanthoma Elasticum Patients. Aging Dis. 2020, 11, 536. [CrossRef]

41. Bellido, T.; O'Brien, C.A.; Roberson, P.K.; Manolagas, S.C. Transcriptional activation of the p21(WAF1,CIP1,SDI1) gene by interleukin-6 type cytokines. A prerequisite for their pro-differentiating and anti-apoptotic effects on human osteoblastic cells. J. Biol. Chem. 1998, 273, 21137-21144. [CrossRef]

42. Choi, J.M.; Rotimi, O.O.; O'Carroll, S.J.; Nicholson, L.F.B. IL-6 stimulates a concentration-dependent increase in MCP-1 in immortalised human brain endothelial cells. F1000Research 2016, 5, 270. [CrossRef]

43. Marino, M.; Scuderi, F.; Provenzano, C.; Scheller, J.; Rose-John, S.; Bartoccioni, E. IL-6 regulates MCP-1, ICAM-1 and IL-6 expression in human myoblasts. J. Neuroimmunol. 2008, 196, 41-48. [CrossRef]

44. Spörri, B.; Müller, K.M.; Wiesmann, U.; Bickel, M. Soluble IL-6 receptor induces calcium flux and selectively modulates chemokine expression in human dermal fibroblasts. Int. Immunol. 1999, 11, 1053-1058. [CrossRef]

45. Lee, W.; Jo, S.; Lee, M.; Won, C.; Lee, M.; Choi, J.; Chang, S. The Effect of MCP-1/CCR2 on the Proliferation and Senescence of Epidermal Constituent Cells in Solar Lentigo. Int. J. Mol. Sci. 2016, 17, 948. [CrossRef] 
46. Marino, M.; Scuderi, F.; Mazzarelli, P.; Mannella, F.; Provenzano, C.; Bartoccioni, E. Constitutive and cytokine-induced expression of MHC and intercellular adhesion molecule-1 (ICAM-1) on human myoblasts. J. Neuroimmunol. 2001, 116, 94-101. [CrossRef]

47. Shelton, D.N.; Chang, E.; Whittier, P.S.; Choi, D.; Funk, W.D. Microarray analysis of replicative senescence. Curr. Biol. 1999, 9, 939-945. [CrossRef]

48. Bauer, C.; le Saux, O.; Pomozi, V.; Aherrahrou, R.; Kriesen, R.; Stölting, S.; Liebers, A.; Kessler, T.; Schunkert, H.; Erdmann, J.; et al. Etidronate prevents dystrophic cardiac calcification by inhibiting macrophage aggregation. Sci. Rep. 2018, 8, 5812. [CrossRef]

49. Hendig, D.; Adam, A.; Zarbock, R.; Szliska, C.; Kleesiek, K.; Götting, C. Elevated serum levels of intercellular adhesion molecule ICAM-1 in Pseudoxanthoma elasticum. Clin. Chim. Acta 2008, 394, 54-58. [CrossRef] [PubMed]

50. Gorgoulis, V.G.; Pratsinis, H.; Zacharatos, P.; Demoliou, C.; Sigala, F.; Asimacopoulos, P.J.; Papavassiliou, A.G.; Kletsas, D. p53-dependent ICAM-1 overexpression in senescent human cells identified in atherosclerotic lesions. Lab. Investig. 2005, 85, 502-511. [CrossRef] [PubMed]

51. Milan-Mattos, J.C.; Anibal, F.F.; Perseguini, N.M.; Minatel, V.; Rehder-Santos, P.; Castro, C.A.; Vasilceac, F.A.; Mattiello, S.M.; Faccioli, L.H.; Catai, A.M. Effects of natural aging and gender on pro-inflammatory markers. Braz. J. Med. Biol. Res. 2019, 52, e8392. [CrossRef]

52. Puzianowska-Kuźnicka, M.; Owczarz, M.; Wieczorowska-Tobis, K.; Nadrowski, P.; Chudek, J.; Slusarczyk, P.; Skalska, A.; Jonas, M.; Franek, E.; Mossakowska, M. Interleukin-6 and C-reactive protein, successful aging, and mortality: The PolSenior study. Immun. Ageing 2016, 13, 21. [CrossRef]

53. Hendig, D.; Langmann, T.; Kocken, S.; Zarbock, R.; Szliska, C.; Schmitz, G.; Kleesiek, K.; Götting, C. Gene expression profiling of $\mathrm{ABC}$ transporters in dermal fibroblasts of pseudoxanthoma elasticum patients identifies new candidates involved in PXE pathogenesis. Lab. Investig. 2008, 88, 1303-1315. [CrossRef]

54. Gibson, K.M.; Hoffmann, G.; Schwall, A.; Broock, R.L.; Aramaki, S.; Sweetman, L.; Nyhan, W.L.; Brandt, I.K.; Wappner, R.S.; Lehnert, W. 3-Hydroxy-3-methylglutaryl coenzyme A reductase activity in cultured fibroblasts from patients with mevalonate kinase deficiency: Differential response to lipid supplied by fetal bovine serum in tissue culture medium. J. Lipid Res. 1990, 31, 515-521. [PubMed]

55. Gary, R.K.; Kindell, S.M. Quantitative assay of senescence-associated beta-galactosidase activity in mammalian cell extracts. Anal. Biochem. 2005, 343, 329-334. [CrossRef] [PubMed]

Publisher's Note: MDPI stays neutral with regard to jurisdictional claims in published maps and institutional affiliations.

(C) 2020 by the authors. Licensee MDPI, Basel, Switzerland. This article is an open access article distributed under the terms and conditions of the Creative Commons Attribution (CC BY) license (http://creativecommons.org/licenses/by/4.0/). 